\title{
St. Augustinegrass accessions planted in northern, central and southern Italy: Growth and morphological traits during establishment
}

\author{
Lisa Caturegli, ${ }^{1}$ Rokhsareh Ramazani, ${ }^{1}$ Marco Volterrani, ${ }^{1}$ Nicola Grossi, ${ }^{1}$ Simone Magni, ${ }^{1}$ \\ Stefano Macolino, ${ }^{2}$ Cristina Pornaro, ${ }^{2}$ Salvatore La Bella, ${ }^{3}$ Teresa Tuttolomondo, ${ }^{3}$ \\ Alberto Minelli, ${ }^{4}$ Monica Gaetani ${ }^{1}$
}

${ }^{1}$ Department of Agriculture, Food and Environment, University of Pisa, Pisa; ${ }^{2}$ Department of Agronomy, Food, Natural resources, Animals and Environment, University of Padova, Legnaro (PD); ${ }^{3}$ Department of Agricultural and Forest Sciences, University of Palermo, Palermo; ${ }^{4}$ Department of Agricultural and Food Sciences, University of Bologna, Bologna, Italy

\begin{abstract}
The use of warm season turfgrasses is a consolidated trend in the climatic transition zone of Mediterranean countries, in particular St. Augustinegrass (Stenotaphrum secundatum (Walt.) Kuntze) begins to be widespread in warm coastal areas. However, little is known about the performance of the different cultivars of this species in southern Europe. In 2016-2017 a trial was carried out in three locations in Italy, Padova, Pisa, and Palermo, located in the north, center and south of the country respectively. Four cultivars (Floratine, Captiva, Sapphire, Palmetto) and five ecotypes (CeRTES 201, CeRTES 202, CeRTES 203, CeRTES 204, CeRTES 205) were compared in terms of their growth characteristics and morphological traits during establishment. The results highlighted that stolon growth was significantly affected by the location, as well as green colour retention. Stolon growth rate, internode length and internode volume and turf quality were, however, significantly determined by the accession effect. The quality of the ecotypes was also in some cases comparable to that of the cultivars. In Padova, winterkill occurred in most of the accessions,
\end{abstract}

Correspondence: Lisa Caturegli, Department of Agriculture, Food and Environment, University of Pisa, via del Borghetto 80, 56124 Pisa, Italy.

E-mail: lisa.caturegli@gmail.com

Key words: Green up; ground cover; internode length; leaf width; Stenotaphrum secundatum; turf quality.

Acknowledgements: the authors gratefully acknowledge Claudia Fantin who assisted with the field measurements at the Experimental Agricultural Farm of Padova University.

Received for publication: 16 June 2018.

Revision received: 23 July 2018.

Accepted for publication: 31 July 2018.

(C) Copyright L. Caturegli et al., 2018

Licensee PAGEPress, Italy

Italian Journal of Agronomy 2018; 13:1294

doi:10.4081/ija.2018.1294

This article is distributed under the terms of the Creative Commons Attribution Noncommercial License (by-nc 4.0) which permits any noncommercial use, distribution, and reproduction in any medium, provided the original author(s) and source are credited. while in Pisa and Palermo, all the entries survived. In conclusion, St. Augustinegrass is suitable for turf use in the central and southern coastal area of Italy.

\section{Introduction}

St. Augustinegrass (Stenotaphrum secundatum (Walt.) Kuntze) is believed to be native to tropical regions, and best adapted to a subtropical climate (Busey, 2003a). It is a widely used lawn grass along the Gulf Coast in the United States, in southern Mexico, throughout the Caribbean region, South America, South Africa, Western Africa, Australia, the South Pacific, and the Hawaiian Islands (Sauer, 1972).

Whereas St. Augustinegrass occurs on all continents except Antarctica, other species of Stenotaphrum occupy restricted natural habitats or are island endemics. For example, $S$. dimidiatum is used in lawns in Kenya, Ghana, Uganda, and India; and S. micranthum (Desv.) C.E. Hubbard is a widely distributed coastal strand pioneer of the Indian Ocean and the South Pacific. S. helferi is distributed from Malaysia through Southeast Asia to southern China, including Hainan Island, it is found along forest paths and serves as good pasture. The other known species of Stenotaphrum are only herbarium specimens and are not cultivated (Busey, 2003a).

St. Augustinegrass grows best in full sun and long day length; however, it is generally considered as one of the most shade tolerant warm season turf species (Winstead and Ward, 1974; Busey, 2003a). Significant differences in degrees of tolerance have been observed within the species (Peacock and Dudeck, 1981). In transition zones, which is an area where neither a cool season grass or a warm season grass will grow well all year around (Dunn and Diesburg, 2004), St. Augustinegrass grows quickly during the summer months, but slowly during spring and fall, and may enter a dormancy period during the winter months if temperatures drop below freezing. Winter survival is a major limiting factor of this species and the most cold-tolerant cultivars available often lack aesthetic characteristics, such as finer leaf texture and shorter internode lengths (Volterrani et al., 1996, 1997; Miele et al., 2000; Croce et al., 2004; Volterrani and Magni, 2004). New St. Augustinegrass cultivars with improved winter survival and turf quality are desired in the turfgrass industry (Busey, 2003b; Kimball et al., 2016).

St. Augustinegrass can grow satisfactorily in a wide variety of soils, but it does not withstand waterlogged or droughty sites (Duble, 1996). It has also been classified as tolerant to salinity, tolerating soil salt levels greater than $10 \mathrm{dS} \mathrm{m}^{-1}$ (Harivandi et al., 
1992). The cultivar Floratine has been reported to be more salt tolerant than bermudagrass (Cynodon spp.) and equal in salinity tolerance to Paspalum vaginatum. Differences in salinity tolerance among several St. Augustinegrass cultivars have been documented. Results of studies conducted by Meyer et al. (1989) and Dudeck et al. (1993) showed that the cultivar Seville was more salt tolerant than cultivars Floratine and Floratam. Although St. Augustinegrass has a lower aesthetic value than other warm season species, it is used primarily for lawns and ornamental turfgrasses and not for sports turf areas because of its poor wear tolerance (Trenholm et al., 2006). Although warm season turfgrasses are commonly used in the transitional areas of Mediterranean countries, little is known about the performance of the different commercial cultivars of St. Augustinegrass in this climatic zone. In addition, considering the high degree of variability of this species (Busey, 2003a), ecotypes have the potential to supply new plant material with the desired turf characteristics.

The first aim of the research was to measure quality parameters to determine the relative turf performance of selected cultivars and ecotypes of St. Augustinegrass in different locations of Italy. The second aim of the research was to measure morphological characteristics and plant biometrics to describe the phenotypic variability observed among the entries (Magni et al., 2014a), which in turn can help to identify promising strains for the selection of new St. Augustinegrass cultivars.

\section{Materials and methods}

A field trial was carried out from May 2016 to May 2017, at the Agricultural Experimental farm of the University of Padova $\left(45^{\circ} 20^{\prime} \mathrm{N}, 11^{\circ} 57^{\prime} \mathrm{E}, 8 \mathrm{~m}\right.$ a.s.l.), at the Centre for Research on Turfgrass for the Environment and Sports (CeRTES) of the

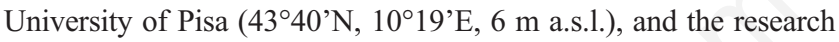
station of the University of Palermo ( $38^{\circ} 06^{\prime} \mathrm{N}, 13^{\circ} 20^{\prime} \mathrm{E}, 50 \mathrm{~m}$ a.s.1.).

The trial included nine St. Augustinegrass accessions, four of which were commercial cultivars (Floratine, Captiva, Sapphire, Palmetto) and five were ecotypes collected from naturally-occur- ring populations. The collection sites of the ecotypes were in the Caribbean (CeRTES 201 = warm, seashore sand), Tunisia (CeRTES 202 = warm, seashore sand), Argentina (CeRTES 203 and CeRTES 204 = warm temperate, dune slacks), and Florida (CeRTES 205 = warm, seashore sand).

Soil types were: i) silty-loam (Oxyaquic Eutrudept, coarsesilty, mixed, mesic: $18 \%$ sand, $63 \%$ silt and $19 \%$ clay) with a $\mathrm{pH}$ of 8 and $27 \mathrm{~g} \mathrm{~kg}^{-1}$ organic matter at the Padova site; ii) silty-loam (Calcaric Fluvisol, 28\% sand, 55\% silt and 17\% clay) with a pH of 7.8 and $18 \mathrm{~g} \mathrm{~kg}^{-1}$ organic matter at the Pisa site; iii) sandy clay loam (Aric. Regosol, 54\% sand, 23\% silt and 23\% clay) with a $\mathrm{pH}$ of 7.6 and $14 \mathrm{~g} \mathrm{~kg}^{-1}$ organic matter at the Palermo site. Temperatures and precipitations recorded during 2016 and 2017 at the three sites are reported in Table 1.

All the accessions were transplanted by a $50 \mathrm{~cm}^{2}$ plug from mature turfgrass stands collected from the research station of the University of Pisa.

Experimental plots were $1.5 \mathrm{~m}$ by $1.5 \mathrm{~m}$ with $0.5 \mathrm{~m}$ bare soil pathways and were arranged in a randomised complete-block design with four replications, with one plug transplanted in the centre of each plot. Transplantation was carried out on 18 May 2016 in Pisa and Padova, and on 19 May 2016 in Palermo. From May to August 2016, all the plots received $50 \mathrm{~kg} \mathrm{ha}^{-1} \mathrm{~N}$ per month from NPK Original Gold 15-9-15 (Compo Expert, Italia). To prevent any possible effect between genotype and mowing, plots were not mown during the experimental period. Weeds were manually removed from plots. The encroachment of stolons into adjacent plots was prevented using toothpicks that redirected the growing tip back toward the plot centre. A sprinkler system was used for irrigation, when needed, to prevent drought stress and encourage establishment.

During the experimental period, the following parameters were assessed:

Ground cover (\%): visual assessments were performed every other week from 14 days after planting (DAP) to 126 DAP.

Stolon growth rate: measured from 42 to 70 DAP by marking with toothpicks the growing tip of two representative stolons in each plot. Elongation was measured weekly with a ruler, and

Table 1. Monthly mean air temperatures and precipitations during trial period (2016 and 2017 up to May), recorded at the trial sites in Padova, Pisa and Palermo.

\begin{tabular}{|c|c|c|c|c|c|c|c|c|c|c|c|c|c|c|c|c|c|c|}
\hline & \multicolumn{6}{|c|}{ Padova } & \multicolumn{6}{|c|}{ Pisa } & \multicolumn{6}{|c|}{ Palermo } \\
\hline & \multicolumn{4}{|c|}{$\begin{array}{l}\text { Mean air temp. } \\
\left({ }^{\circ} \mathrm{C}\right)\end{array}$} & \multicolumn{2}{|c|}{$\begin{array}{l}\text { Precipitation } \\
\text { (mm) }\end{array}$} & \multicolumn{4}{|c|}{$\begin{array}{l}\text { Mean air temp. } \\
\left({ }^{\circ} \mathrm{C}\right)\end{array}$} & \multicolumn{2}{|c|}{$\begin{array}{l}\text { Precipitation } \\
\text { (mm) }\end{array}$} & \multicolumn{4}{|c|}{$\begin{array}{c}\text { Mean air temp. } \\
\left({ }^{\circ} \mathrm{C}\right)\end{array}$} & \multicolumn{2}{|c|}{$\begin{array}{l}\text { Precipitation } \\
\text { (mm) }\end{array}$} \\
\hline & \multicolumn{2}{|c|}{2016} & \multicolumn{2}{|c|}{2017} & \multirow[t]{2}{*}{2016} & \multirow[t]{2}{*}{2017} & \multicolumn{2}{|c|}{2016} & \multicolumn{2}{|c|}{2017} & \multirow[t]{2}{*}{2016} & \multirow[t]{2}{*}{2017} & \multicolumn{2}{|c|}{2016} & \multicolumn{2}{|c|}{2017} & \multirow[t]{2}{*}{2016} & \multirow[t]{2}{*}{2017} \\
\hline & $\min$ & $\max$ & $\min$ & $\max$ & & & $\min$ & $\max$ & $\min$ & $\max$ & & & $\min$ & $\max$ & $\min$ & $\max$ & & \\
\hline Jan. & -0.5 & 7.5 & -8.0 & 2.6 & 31 & 14 & 4.6 & 11.4 & 1.8 & 9.9 & 143 & 41 & 10.9 & 15.9 & 2.8 & 17.7 & 69 & 133 \\
\hline Feb. & 4.2 & 11.2 & -1.7 & 7.1 & 145 & 7 & 6.6 & 13.0 & 6.1 & 14.0 & 203 & 89 & 11.9 & 17.2 & 7.9 & 24.5 & 28 & 76 \\
\hline Mar. & 5.2 & 14.4 & 0.8 & 10.8 & 45 & 12 & 6.2 & 14.8 & 6.9 & 17.0 & 44 & 48 & 11.0 & 16.9 & 8.7 & 23.2 & 92 & 20 \\
\hline Apr. & 9.1 & 19.0 & 2.4 & 13.5 & 21 & 56 & 9.7 & 19.3 & 8.3 & 19.3 & 41 & 20 & 13.7 & 20.5 & 9.9 & 29.9 & 14 & 34 \\
\hline May & 11.9 & 21.7 & 7.2 & 19.4 & 192 & 40 & 12.0 & 21.4 & 12.6 & 23.3 & 82 & 32 & 15.8 & 21.4 & 12.4 & 34.6 & 51 & 0 \\
\hline June & 16.5 & 26.9 & - & - & 134 & - & 16.1 & 24.8 & - & - & 81 & - & 19.9 & 25.8 & - & - & 32 & - \\
\hline July & 19.0 & 30.1 & - & - & 58 & - & 18.4 & 29.4 & - & - & 5 & - & 22.5 & 28.5 & - & - & 3 & - \\
\hline Aug. & 17.2 & 28.5 & - & - & 51 & - & 18.2 & 29.4 & - & - & 37 & - & 22.7 & 28.4 & - & - & 9 & - \\
\hline Sept. & 15.2 & 26.7 & - & - & 67 & - & 16.2 & 27.1 & - & - & 165 & - & 21.1 & 26.0 & - & - & 52 & - \\
\hline Oct. & 9.4 & 17.5 & - & - & 119 & - & 11.9 & 20.4 & - & - & 106 & - & 17.9 & 24.6 & - & - & 101 & - \\
\hline Nov. & 6.1 & 12.5 & - & - & 135 & - & 8.4 & 16.1 & - & - & 123 & - & 14.2 & 20.3 & - & - & 47 & - \\
\hline Dec. & -0.3 & 7.6 & - & - & 0 & - & 3.6 & 13.6 & - & - & 5 & - & 11.5 & 16.9 & - & - & 40 & - \\
\hline
\end{tabular}


data were reported as average weekly elongation $\left(\mathrm{mm} \mathrm{week}^{-1}\right)$ (Magni et al., 2014a).

- Colour and quality: two visual assessments on 70 DAP and 126 DAP (colour with a rating scale of $1=$ light green and $9=$ dark green, quality with a rating scale of $1=$ poorest and $9=$ best) according to the National Turfgrass Evaluation Program (NTEP, 2012).

- Internode diameter: measured by a micrometer (Digimatic, Mitutoyo Corp. Japan) on ten node-internode units randomly collected from ten stolons at 119 DAP. To take measurements only on mature tissues, the first four internodes from the stolon tip downward were discarded (Magni et al., 2014b).

- Internode length: measured at 119 DAP with a precision Vernier caliper selecting internodes lengths as for the internode diameter (Magni et al., 2014b).

- Internode volume: calculated as $(0.5 \times \text { internode diameter })^{2} \times$ $\pi \times$ internode length, and reported in cubic millimeters (Magni et al., 2014b).

- Leaf width and leaf length: 20 fully expanded leaves per plot were measured at 119 DAP with a precision Vernier caliper (only at the Pisa site) (Magni et al., 2014a).

- Fall colour retention was biweekly estimated from October 2016 to December 2016 and expressed as the percentage of green cover. Data reported refer to 21 December when some of the entries were below $30 \%$ green cover (NTEP, 2012).

- Spring green up was estimated from April 2017 to May 2017 and expressed as the percentage of green cover. Data reported refer to 31 May when some of the entries first exceeded the $70 \%$ threshold (NTEP, 2012).

Data were subjected to analysis of variance using CoStat software (version 6.400, CoHort software, Monterey, CA, USA). Significant different means were separated using Fisher's least significant difference (LSD) at the t-probability level of 0.05 .

\section{Results and discussion}

There was interaction between the location and accession regarding the ground cover parameter. For the other parameters, the effects in some cases of location, accession or their interaction were significant (Table 2).

\section{Interaction locations $\times$ accessions}

For the ground cover percentage, values refer to 126 DAP when at least one cultivar had reached $100 \%$ ground cover. This parameter was affected by the interaction between entries and locations.

In Padova, Floratine and CeRTES 202 showed a higher percentage (93\% and 91\%), which differed, significantly from CeRTES 203, CeRTES 204, Sapphire and Palmetto (Table 3).
In Pisa, a higher ground cover percentage was observed in CeRTES 202 (64\%), Captiva (57\%) and Floratine (55\%), and the other cultivars scored values ranging from $23 \%$ (Certes 204) to $51 \%$ (Certes 201). In Palermo the first entry to reach 100\% ground cover was CeRTES 201, which was not statistically different from CeRTES 205 (81\%) and Captiva (75\%), furthermore CeRTES 201 which at 126 DAP registered a $100 \%$ ground cover in Palermo, was not significantly different from CeRTES 201 (71\%), CeRTES 202 (91\%), CeRTES 205 (78\%) and Floratine (93\%) in Padova. All values recorded by the accessions in Pisa, were significantly lower than $100 \%$. Considering the performances of the cultivars in the three locations, among the ecotypes, the worst performances were registered by CeRTES 203 and CeRTES 204, the best by CeRTES 201 and CeRTES 205 (with the exception of Pisa).

Among cultivars, the performances highlight the differences in establishment between the three locations, with Floratine showing good performances in Padova and poor performances at the other experimental stations.

\section{Location main effect}

During the establishment, the stolon growth rate was significantly affected by location. Measurements taken from 42 to 70 DAP showed a higher rate in Padova $\left(5.2 \mathrm{~cm} \mathrm{week}^{-1}\right)$ compared with Pisa and Palermo (3.6 $\mathrm{cm} \mathrm{week}^{-1}$ ) (Table 4), probably due to the influence of higher precipitations during the establishment months (Table 1), as also reported by Erickson et al. (2010). At 119 DAP, in Padova, where the stolon growth rate was higher, stolon internodes were significantly thicker $(5.6 \mathrm{~mm})$ and showed a higher volume $\left(907 \mathrm{~mm}^{3}\right)$ compared with the other two locations. Regarding internode length, Pisa registered the lowest value with $3.3 \mathrm{~cm}$. Based on this observation, internode length did not seem to contribute to overall stolon growth, while stolon tip growth rate appeared to be influenced by internode reserve and carbohydrate accumulation, related to the internode diameter and volume (Table 4) (Gaetani et al., 2017). The overall quality was relatively low, and Palermo showed the lowest ratings (4.5), while Padova and Pisa did not differ significantly from one another (6.0 and 5.8 respectively). Another important parameter that was significantly affected by location was the fall colour retention determined on December 21, 2016 (Table 4), where Palermo registered a higher green colour percentage (54\%) than the other two locations. This difference in colour retention could be due to the different meteorological conditions recorded in the three locations. In December minimum and maximum air temperatures were higher at Palermo than Padova and Pisa (Table 1).

\section{Accession main effect}

Stolon growth rate, internode length and internode volume and turf quality were also significantly affected by the main effect of accession (Table 5), while internode diameter was not significant.

Table 2. Results of analysis of variance testing the effects of location, accessions and their interactions on ground cover percentage [126 days after planting (DAP)], stolon growth rate (42-70 DAP), colour, turf quality (mean values 70-126 DAP), internode diameter, internode length, internode volume (119 DAP), fall colour retention (December 21 2016), and spring green-up (May 31 2017, Pisa and Palermo).

\begin{tabular}{|c|c|c|c|c|c|c|c|c|c|}
\hline Effect & $\begin{array}{l}\text { Ground } \\
\text { cover }\end{array}$ & $\begin{array}{c}\text { Stolon } \\
\text { growth rate }\end{array}$ & Colour & $\begin{array}{l}\text { Turf } \\
\text { quality }\end{array}$ & $\begin{array}{l}\text { Int. } \\
\text { diam. }\end{array}$ & $\begin{array}{l}\text { Int. } \\
\text { length }\end{array}$ & $\begin{array}{l}\text { Int. } \\
\text { volume }\end{array}$ & $\begin{array}{l}\text { Fall colour } \\
\text { ret. }\end{array}$ & $\begin{array}{l}\text { Spring } \\
\text { green-up }\end{array}$ \\
\hline Location (L) & $*$ & $*$ & NS & * & $*$ & * & $*$ & $*$ & NS \\
\hline Accession (A) & $*$ & $*$ & NS & $*$ & NS & $*$ & $*$ & NS & $*$ \\
\hline $\mathrm{LxA}$ & $*$ & NS & NS & NS & NS & NS & NS & NS & NS \\
\hline
\end{tabular}

*Significant $\mathrm{F}$ test at the 0.05 level of probability. NS not significant at the 0.05 level of probability. 
In the period of greatest growth (42-70 DAP), CeRTES 205, CeRTES 201, and Floratine registered a significantly higher stolon growth rate (ranging from 4.7 to $4.9 \mathrm{~cm} \mathrm{wk}^{-1}$ ). For internode length, Floratine scored the highest value $(5.4 \mathrm{~cm})$, while all the other ecotype and commercial accessions registered significantly lower values, ranging from $3.0 \mathrm{~cm}$ (Sapphire) to $3.7 \mathrm{~cm}$ (CeRTES 201, CeRTES 205). Floratine also scored a higher internode volume $\left(845 \mathrm{~mm}^{3}\right)$, although it did not significantly differ from CeRTES 201, CeRTES 202, CeRTES 203, Captiva and Palmetto. The highest turf quality was shown by CeRTES 201, which did not differ statistically only from CeRTES 202 (6.4 and 6.0 respectively). The commercial cultivars scored insufficient values (average value 5) contrary to what registered in the NTEP (2016) and observed by Marchione and Fracchiolla (2016) for the cv Palmetto in a trial in Southern Italy. Of all the accessions, the internode length showed evident different, with Floratine showing the highest value $(5.4 \mathrm{~cm})$ (Table 5).
Table 3. Ground cover percentage (126 days after planting) when one accession (CeRTES 201) reached full ground cover in one location. Interaction location $\times$ accession.

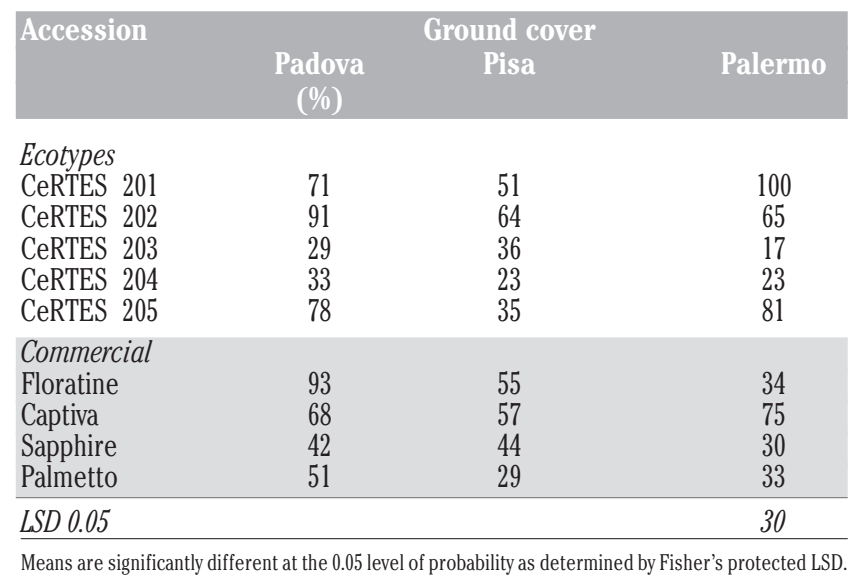

Table 4. Stolon growth rate [42-70 days after planting (DAP)], internode length, internode diameter (119 DAP), internode volume, turf quality (visual estimation based on 1-9 scale, mean values 70-126 DAP) determined during 2016, and fall colour retention assessed on December 21, 2016. Location main effect.

\begin{tabular}{|c|c|c|c|c|c|c|}
\hline Location & $\begin{array}{l}\text { Stolon } \\
\text { growth rate } \\
\left(\mathrm{cm} \mathrm{wk}^{-1}\right)\end{array}$ & $\begin{array}{l}\text { Internode } \\
\text { length } \\
\text { (cm) }\end{array}$ & $\begin{array}{l}\text { Internode } \\
\text { diameter } \\
(\mathrm{mm})\end{array}$ & $\begin{array}{l}\text { Internode } \\
\text { volume } \\
\left(\mathrm{mm}^{3}\right)\end{array}$ & $\begin{array}{l}\text { Turf } \\
\text { quality } \\
(1-9)\end{array}$ & $\begin{array}{l}\text { Fall colour } \\
\text { retention } \\
(\%)\end{array}$ \\
\hline Padova & 5.2 & 3.8 & 5.6 & 907 & 6.0 & 30 \\
\hline Pisa & 3.6 & 3.3 & 4.3 & 464 & 5.8 & 28 \\
\hline Palermo & 3.6 & 4.1 & 3.2 & 317 & 4.5 & 54 \\
\hline LSD 0.05 & 1.0 & 0.5 & 0.5 & 170 & 1.0 & 10 \\
\hline
\end{tabular}

Means are significantly different at the 0.05 level of probability as determined by Fisher's protected LSD.

Table 5. Stolon growth rate [42-70 days after planting (DAP)], internode length (119 DAP), internode volume and turf quality (visual estimation based on 1-9 scale, mean values 70-126 DAP). Accession main effect.

\begin{tabular}{lcccc} 
Accession & Stolon growth rate $\left(\mathrm{cm} \mathrm{wk}^{-1}\right)$ & Internode length $(\mathrm{cm})$ & Internode volume $\left(\mathrm{mm}^{3}\right)$ & Turf quality $(1-9)$ \\
Ecotypes & & & 628 & 6.4 \\
CeRTES 201 & 4.7 & 3.7 & 544 & 6.0 \\
CeRTES 202 & 4.5 & 3.6 & 585 & 5.1 \\
CeRTES 203 & 2.7 & 3.5 & 375 & 4.9 \\
CeRTES 204 & 2.4 & 3.1 & 495 & 5.8 \\
CeRTES 205 & 4.9 & 3.7 & 845 & 5.1 \\
Commercial & & & 482 & 5.0 \\
Floratine & 4.7 & 5.4 & 326 & 5.8 \\
Captiva & 4.2 & 3.6 & 501 & 5.0 \\
Sapphire & 3.5 & 3.0 & 311 & 0.6 \\
Palmetto & 3.7 & 3.6 & 0.9 & \\
\hline LSD 0.05 & 1.8 & &
\end{tabular}

Means are significantly different at the 0.05 level of probability as determined by Fisher's protected LSD.

Table 6. Spring green-up (\% green colour) determined on May 31, 2017. Leaf width and leaf length (mm) were only measured in Pisa location (119 days after planting). Accession main effects.

\begin{tabular}{|c|c|c|c|}
\hline Accession & Spring green-up* (\%) & Leaf width" $(\mathrm{mm})$ & Leaf length"\# $(\mathrm{cm})$ \\
\hline $\begin{array}{l}\text { Ecotypes } \\
\text { CeRTES } 201 \\
\text { CeRTES } 202 \\
\text { CeRTES } 203 \\
\text { CeRTES } 204 \\
\text { CeRTES } 205\end{array}$ & $\begin{array}{l}65 \\
60 \\
70 \\
50 \\
63\end{array}$ & $\begin{array}{l}6.2 \\
7.2 \\
5.7 \\
4.7 \\
6.4\end{array}$ & $\begin{array}{l}3.3 \\
3.2 \\
2.7 \\
2.7 \\
4.9\end{array}$ \\
\hline $\begin{array}{l}\text { Commercial } \\
\text { Floratine } \\
\text { Captiva } \\
\text { Sapphire } \\
\text { Palmetto }\end{array}$ & $\begin{array}{l}54 \\
74 \\
70 \\
70\end{array}$ & $\begin{array}{l}6.2 \\
5.7 \\
4.9 \\
5.6\end{array}$ & $\begin{array}{l}4.0 \\
2.9 \\
2.5 \\
2.6\end{array}$ \\
\hline LSD 0.05 & 18 & 1.4 & 0.7 \\
\hline
\end{tabular}

Means are significantly different at the 0.05 level of probability as determined by Fisher's protected LSD. *Measured only in Pisa and Palermo location; ${ }^{*}$ measured only in Pisa location. 
Another important parameter affected by accession main effect was the spring green up which was only measured in Pisa and Palermo (Table 2). In Padova, probably due to the lower temperatures (Table 1), only four cultivars (with some shoots per plot) CeRTES 203 and 204 among ecotypes, and Captiva and Palmetto among the commercial cultivars, survive the winter period. In a study where Kimball et al. (2017), assessed the freeze tolerance in St. Augustinegrass with temperatures between -3 and $-4^{\circ} \mathrm{C}$, the genotypes studied appeared to fall within three distinct groupings, in which Captiva and Palmetto were included in the intermediate sensitive group. Thus, the species does not tolerate the cold winter of this latitude (winterkill damage). In fact, the absence of underground stems, such as rhizomes, exposes St. Augustinegrass to damage from the cold (DiPaola and Beard, 1992; Busey, 2003b). As a mean of two locations (Pisa and Palermo), on May 31, 2017 the fastest accessions in the green up were all the commercial types (Table 6), with the exception of Floratine and the ecotypes CeRTES 201, CeRTES 203, and CeRTES 205.

In terms of leaf width and leaf length, measured only in the Pisa location at 119 DAP, the highest value of leaf width among all the accessions was observed in CeRTES $202(7.2 \mathrm{~mm})$ which was statistically not different from CeRTES 201, CeRTES 205 and Floratine (Table 6). As for leaf length, the highest value was recorded for CeRTES $205(4.9 \mathrm{~cm})$, which was significantly different from all the other entries.

\section{Conclusions}

The establishment trial of Stenotaphrum secundatum highlighted the following key points: during the establishment year, stolon growth was significantly affected by the location, as well as the green colour retention in the fall. The stolon growth rate, internode length and volume and turf quality were, however, significantly determined also by the accession effect. The ecotype turf quality was in some cases higher than the commercial cultivars that performed poorly. In addition, some ecotype registered leaf width and leaf length values that were close and, in some cases lower to commercial cultivars.

At the spring vegetative recovery of Stenotaphrum secundatum, during the second year of the trial, we were able to partially quantify the resistance to cold of the species. The absence of underground stems such as rhizomes exposes this species to damage from the cold more than other warm season species such as bermudagrass (Cynodon spp.) or zoysiagrass (Zoysia spp.). In the case of Padova in fact, the cultivars, with a few exceptions, did not tolerate the cold winter of this latitude. In conclusion, Stenotaphrum secundatum, because of its limited resistance to low temperatures, is suitable for turf use only in the central/southern coastal areas of Italy.

Further investigations will be necessary in these areas to evaluate the real suitability of some ecotypes, particularly CeRTES 201 , that have distinguished themselves for good turf quality characteristics and growth rate.

\section{References}

Busey P, 2003a. St. Augustinegrass, Stenotaphrum secundatum (Walt.) Kuntze. In: Casler, M.D. and R.R. Duncan (Eds.), Biology, breeding, and genetics of turfgrasses. John Wiley \& Sons, Inc., Hoboken, NJ, USA, pp. 309-330.
Busey P, 2003b. Winter survival of St. Augustinegrass cultivars. HortSci. 38:1439-40.

Croce P, De Luca A, Mocioni M, Volterrani M, Beard JB, 2004. Adaptability of warm season turfgrass species and cultivars in a Mediterranean climate. Acta Hort. 61:365-8.

DiPaola JM, Beard JB, 1992. Physiological effects of temperature stress. In: D.V. Waddington, R.N. Carrow, R.C. Shearman (Eds.), Turfgrass. Agronomy monograph $N^{\circ} 32$, American Soc. of Agronomy, Madison, WI, USA, pp. 231-267.

Duble RL, 1996. Turfgrasses: their management and use in the southern zone. Second Edition. Texas A\&M University Press, TX, USA.

Dudeck AE, Peacock CH, Wildmon JC, 1993. Physiological and growth responses of St. Augustinegrass cultivars to salinity. HortSci. 28:46-8.

Dunn J, Diesberg K. 2004. Turf Management in the Transition Zone. John Wiley, Hoboken, NJ, USA.

Erickson JE, Park DM, Cisar JL, Snyder GH, Wright AL, 2010. Effects of sod type, irrigation, and fertilization on nitrate-nitrogen and orthophosphate-phosphorus leaching from newly established St. Augustinegrass sod. Crop Sci. 50:1030-6.

Gaetani M, Volterrani M, Magni S, Caturegli L, Minelli A, Leto C, La Bella S, Tuttolomondo T, Virga G, Grossi N, 2017. Seashore paspalum in the Mediterranean transition zone: phenotypic traits of twelve accessions during and after establishment. Ital. J. Agron. 12:110-5.

Harivandi MA, Butler JD, Wu L, 1992. Salinity and turfgrass culture. In: D.V. Waddington, R.N. Carrow, R.C. Shearman (Eds.), Turfgrass. Agronomy monograph $\mathrm{N}^{\circ} 32$, American Soc. of Agronomy Madison, WI, USA, pp. 207-229.

Kimball JA, Isleib TG, Reynolds WC, Zuleta MC, Milla-Lewis SR, 2016. Combining ability for winter survival and turf quality traits in St. Augustinegrass. HortSci. 51:810-5.

Kimball JA, Tuong TD, Arellano C, Livingston DPIII, Lewis SRM, 2017. Assessing freeze-tolerance in St. Augustinegrass: temperature response and evaluation methods. Euphytica 213:110.

Magni S, Gaetani M, Caturegli L, Leto C, Tuttolomondo T, La Bella S, Virga G, Ntoulas N, Volterrani M, 2014b. Phenotypic traits and establishment speed of 44 turf bermudagrass accessions. Acta Agric. Scand. B. 64:722-33.

Magni S, Gaetani M, Grossi N, Caturegli L, La Bella S, Leto C, Virga G, Tuttolomondo T, Lulli F, Volterrani M, 2014a. Bermudagrass adaptation in the Mediterranean climate: phenotypic traits of 44 accessions. Adv. Hort. Sci. 28:29-34.

Marchione V, Fracchiolla M, 2016. Performance of warm-season turfgrasses under different water regimes in the Mediterranean climate conditions of Southern Italy. Ital. J. Agron. 11:158-63.

Meyer MJ, Smith MAL, Knight SL, 1989. Salinity effects on St. Augustinegrass: a novel system to quantify stress response. J. Plant Nutr. 12:893-908.

Miele S, Volterrani M, Grossi N, 2000. Warm season turfgrasses: result of a five-year study in Tuscany. Agr. Med. 130:1-9.

National Turfgrass Evaluation Program (NTEP), 2012. National turfgrass evaluation program, Beltsville, MD. Available from: http://www.ntep.org Accessed: 20 $0^{\text {th }}$ July, 2018.

National Turfgrass Evaluation Program (NTEP), 2016. National St. Augustinegrass Test, Beltsville, MD. Available from: http://www.ntep.org Accessed: 20 $0^{\text {th }}$ July, 2018.

Peacock CH, Dudeck AE, 1981. Effects of shade on morphological and physiological parameters of St. Augustinegrass cultivars. pp. 493-500 in Proc. $4^{\text {th }}$ Intl. Turfgrass Res. Conference, Ontario, Canada. 
Sauer JD, 1972. Revision of Stenotaphrum (Gramineae: Paniceae) with attention to its historical geography. Brittonia 24:202-22.

Trenholm LE, Cisar JL, Unruh JB, 2006. St. Augustinegrass for Florida lawns. Florida Coop. Ext. Service, Inst. of Food. and Agric. Sci., Univ. of Florida, Gainesville, FL, USA. Available from: http://edis.ifas.ufl.edu/LH010

Volterrani M, Grossi N, Pardini G, Miele S, Gaetani M, Magni S, 1997. Warm season turfgrass adaptation in Italy. Int. Turfgrass Soc. Res. J. 8:1344-54.
Volterrani M, Magni S, 2004. Species and growing media for sports turfs in Mediterranean area. ActaHort. 661:359-64.

Volterrani M, Pardini G, Grossi N, Miele S, Gaetani M, Pietrini E, 1996. Valutazione dell'adattabilità di specie graminacee macroterme da tappeti erbosi alle condizioni ambientali dell'Italia centrale. Italus Hortus 3:10-6.

Winstead CW, Ward CY, 1974. Persistence of southern turfgrasses in a shade environment. pp. 221-230 in Proc. $2^{\text {nd }}$ Intl. Turfgrass Res. Conference, Blacksburg, VA, USA. 